\title{
Bone development in sow-reared piglets during the 1st month of life
}

\author{
By M. J. MANNERS A.ND M. R. McCREA \\ Department of Animal Husbandry, School of Veterinary Science, \\ University of Bristol
}

(Received I4 December 1962-Revised 25 fuly 1963)

In recent years studies have been made of the minimum levels of calcium, phosphorus and magnesium necessary in diets for artificially reared piglets (Mayo, Plumlee \& Beeson, 1959; Rutledge, Hanson \& Meade, 196r ; Miller, Ullrey, Zutaut, Baltzer, Schmidt, Hoefer \& Luecke, 1962 ; Combs, Vandepopuliere, Wallace \& Koger, 1962). Though bone development was measured in these studies, in none of them were sow-reared litter-mates used as controls. Kossakowski (1962a, $b$ ) presented data on measurements and weight of a number of bones in the pig at birth and at the ages of 2, 4, 6, about 9, 12 and about 33 months. Dickerson (1962) has reported data on the composition of the humerus of pig foetuses at 46,65 and 90 days of gestation and of newborn, 20-45, 65-143 days old, and of I-year-old pigs. It seemed to us that there was a need for data on bone development in suckled pigs in the period just after birth so that experiments on the minimum requirements of very young pigs for boneforming minerals could be better interpreted.

The object of the study now described was to investigate the normal pattern of bone development in the suckled piglet during the ist month of life. Such information is of theoretical interest as representative of normal bone development in a rapidly growing young animal. The prolificacy of the sow enables a series of young animals of very similar breeding, the same uterine environment, and receiving the same maternal milk supply to be examined. Thus with a small number of animals the trends of normal growth should become apparent with the minimum of complication from genetic and environmental effects.

\section{EXPERIMENTAL}

Animals and their management. Four litters of Large White $\times$ Wessex piglets which each contained at least six piglets of uniform birth weight were used. Individuals were slaughtered in turn, a piglet from each litter being killed at $0,2,7,14,21$ and 28 days of age. The significance of differences between means for the characteristics measured was tested by analysis of variance.

The sows and litters were housed in wooden huts with concrete-floored outside runs. Piglets were creep-fed from 3 weeks of age. Anti-anaemia paste (500 mg reduced iron per dose; Boots Pure Drug Co. Ltd) was given at 2 and 7 days of age. In one of the litters enough piglets of similar initial weight were available for further slaughter at 56,84, I 22 and I 40 days of age. In an attempt to ensure adequate miner al 
intake these older pigs were given creep feed ad lib. until $\mathrm{i} 2$ weeks old and were then given sow-and-weaner pellets according to scale B of Woodman (1957). The calculated composition of the creep feed was $\mathrm{I} \cdot 2 \% \mathrm{Ca}, 0.7 \% \mathrm{P}$ and $0.12 \% \mathrm{Mg}$. The sow-andweaner pellets contained $\mathrm{I} \cdot 0 \% \mathrm{Ca}, 0.6 \% \mathrm{P}$ and $0.20 \% \mathrm{Mg}$.

Slaughter and dissection procedure. After weighing, piglets were killed by intraperitoneal injection of a solution containing pentobarbitone sodium. The radius, ulna, and $3^{\text {rd }}$ and $4^{\text {th }}$ metacarpals from both front limbs were selected for detailed study. Bones of the fore limb were chosen because in our experience this limb had shown greater proneness to distortion on artificial diets low in bone-forming minerals (McCrea $\&$ Tribe, 1956). It was found easier to dissect the bones out in one operation rather than to remove them with the adherent tissues and try to separate these later. The bones were removed complete with periosteum and were weighed and measured immediately. They were then left to dry in the laboratory for a day or so.

Chemical methods. For the determination of fat, bones were placed in Soxhlet extractors and were extracted with light petroleum (b.p. $40-60^{\circ}$ ) for 24 h. After the solvent had been evaporated the fat was weighed. It is possible that some watersoluble $\mathrm{P}$ was removed by this procedure. After being dried at $100^{\circ}$ for $\mathrm{I} 6 \mathrm{~h}$ the fatfree bones were cooled and weighed, and then ashed in silica evaporating basins at $60^{\circ}$ for $6 \mathrm{~h}$. For the measurement of $\mathrm{Ca}, \mathrm{P}$ and $\mathrm{Mg}$ in the $3^{\text {rd metacarpal and radius }}$ the ash was dissolved in hydrochloric acid (sp. gr. $1 \cdot 18$ ) at the rate of $3 \mathrm{ml}$ acid/g ash. The solution was then boiled gently for $30 \mathrm{~min}$, cooled and made up to a known volume. Ca was measured in triplicate samples by the method of Clark \& Collip (1925), $P$ in duplicate samples by the method of Hanson (1950) and $\mathrm{Mg}$ in duplicate samples by the method of Bradfield (1961). Recoveries of all three elements were checked by the inclusion in each batch of samples of a synthetic solution containing $\mathrm{Ca}, \mathrm{P}$ and $\mathrm{Mg}$ in the ratio of $60: 30: 1$.

\section{RESUI.TS}

\section{Four litters studied over the period from 0 to 28 days of age}

Weight gain. It is not known to what extent the progressive reduction in litter size which occurred during the experiment may have influenced the growth rate of the survivors. The growth of the piglets was rapid, those slaughtered at 4 weeks of age weighing over seven times as much as those killed at birth (see Table r). With allowance for the increase in total body fat that occurs between farrowing and 4 weeks of age (Manners \& McCrea, 1963), these 4-week-old piglets would have contained about six times as much fat-free body tissue as did their litter-mates at birth. Relative rates of weight gain, i.e. daily gain between one slaughter age and the next expressed as a percentage of the weight at the earlier age, were $11 \cdot 9,15.7,8 \cdot 5,7.6$ and 4.7 for $0-2$, $2-7,7-14,14-21$ and $21-28$ days respectively. Thus the maximum rate of gain occurred between 2 and 7 days of life with successively smaller rates of increase thereafter. Our investigation of total body composition of piglets of the same breeding has shown that the relative rates of gain of fat-free body tissue are of the same pattern as that found for total gain (Manners \& McCrea, 1963).

Bone weight. At 4 weeks of age fresh bone weights of the $3^{\text {rd metacarpal, }} 4^{\text {th }}$ meta- 
carpal, radius and ulna were, respectively, $5 \cdot 82,5 \cdot 74,5 \cdot 83$ and $5 \cdot 25$ times those at birth. The weights of ash in the same bones were $6.46,7 \cdot 59,6.48$ and 6.42 times those at birth. Since the $4^{\text {th }}$ metacarpal showed the greatest increase in ash content over the Ist month of life it would seem likely to be the most sensitive bone (of the four studied) for experiments to determine the mineral requirement for optimum bone formation over this period. Relative rates of gain in weight of bones were greatest between 2 and 7 days of age. For example, in the 4 th metacarpal daily gains in weight between one slaughter age and the next, expressed as a percentage of the weight at the earlier age, were $5.5,14.8,7.5,7.5$ and 4.0 for $0-2,2-7,7-14,14-21$ and $21-28$ days respectively.

Table I. Mean values with their standard errors for weight at slaughter, bone weights

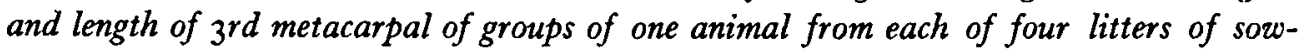
reared piglets slaughtered in turn during the ist month of life

\begin{tabular}{|c|c|c|c|c|c|c|}
\hline Age at slaughter (days) . & $\cdots$ & 2 & 7 & $x_{4}$ & $2 x$ & 28 \\
\hline No. and sex & 23,27 & $10^{*}, 39$ & $13,3 \%$ & $20,2 q$ & $30^{t}, 19$ & 15,39 \\
\hline $\begin{array}{l}\text { Weight at } \\
\text { slaughter }(\mathrm{kg})\end{array}$ & $1.412 \pm 0.0$ & $747 \pm 0.0$ & $10+0.2$ & 397 & $7 \cdot 597 \pm$ & $8+0.618$ \\
\hline $\begin{array}{l}\text { 3rd metacarpal } \\
\text { 4th metacarpal } \\
\text { Radius } \\
\text { Ulna }\end{array}$ & $\begin{array}{l}: \\
0.986 \pm 0.071 \\
0.862 \pm 0.055 \\
2.591 \pm 0.157 \\
2.954 \pm 0.217\end{array}$ & $\begin{array}{l}1 \cdot 112 \pm 0.045 \\
0.956 \pm 0.039 \\
3.030 \pm 0.133 \\
3.288 \pm 0.134\end{array}$ & $\begin{array}{l}1.851 \pm 0.169 \\
1.665 \pm 0.157 \\
4.980 \pm 0.383 \\
5.449 \pm 0.381\end{array}$ & $\begin{array}{l}2.784 \pm \\
2.539 \pm \\
7.364 \pm\end{array}$ & $\begin{array}{r}4.209 \pm 0.192 \\
3.879 \pm 0.168 \\
11.484 \pm 0.587 \\
12.271 \pm 0.712\end{array}$ & $\begin{array}{r}5 \cdot 736 \pm \\
4 \cdot 955 \pm \\
15 \cdot 096 \pm \\
15 \cdot 521 \pm\end{array}$ \\
\hline & & $56 \pm 0$ & $2.84 \pm 0$ & $.29 \pm 0.06$ & $3.86 \pm 0.07$ & $4.28 \pm 0.07$ \\
\hline
\end{tabular}

Chemical composition of bones. The figures for ash content of the radius and $3^{\text {rd }}$ metacarpal and for the composition of the ash of the $3^{\text {rd metacarpal are for one bone }}$ from each pig only. All other values in the tables are means for the bones from both front limbs. Table 2 shows that, in all four bones studied, the percentages of fat, fatfree dry matter and ash showed similar trends during the period.

Fat content of fresh bones. Throughout the first 4 weeks of life the percentage of fat in the fresh bones was low, rising from $0.21-0.28$ at birth to $0.39-1.04$ at 28 days. During this period fat deposition within the rest of the body of the piglet is considerable (Manners \& McCrea, 1963 ) and it is surprising that percentages of fat in bone remained so low for as long as 28 days. The small changes in fat content that were observed were of doubtful statistical significance. In other (unpublished) experiments we have found that the fat content of bone is almost always considerably higher at 28 days of age in artificially reared piglets than in their sow-reared littermates.

Fat-free dry-matter content of bones. In the $3^{\text {rd }}$ and $4^{\text {th }}$ metacarpals and the radius fat-free dry matter percentage at 21 and 28 days was significantly higher than at earlier ages. In the $4^{\text {th }}$ metacarpal the figures for 14-day slaughtered animals were also significantly higher than at earlier ages. Fat-free dry matter in the radius at 7 days of age was lower than at 0,2 or 14 days of age $(P<0.01)$.

Ash content of fresh bones. The significance of differences between values for this 
characteristic showed the same pattern as found for fat-free dry-matter content, with the ulna showing the same pattern as the metacarpals. There was a fall in ash concentration between birth and 7 days of age in each of the four bones studied, but only for the radius was it statistically significant $(P<0.05)$.

Table 2. Mean values and standard errors of differences between means for percentage fat, fat-free dry matter and ash in fresh bone, and percentage ash in fat-free dry bone of groups of one animal from each of four litters of sow-reared piglets slaughtered in turn during the ist month of life

\begin{tabular}{|c|c|c|c|c|c|c|c|}
\hline $\begin{array}{l}\text { Age at slaughter } \\
\text { (days) } \quad \ldots\end{array}$ & $\circ$ & 2 & 7 & 14 & 21 & 28 & $\begin{array}{l}\text { of difference } \\
\text { between } \\
\text { means }\end{array}$ \\
\hline \multicolumn{8}{|l|}{ Fat in fresh bone: } \\
\hline 3rd metacarpal & 0.27 & 0.39 & 0.51 & 0.70 & 0.54 & $I \cdot 04$ & 0.19 \\
\hline 4th metacarpal & 0.22 & 0.39 & 0.54 & 0.60 & 0.41 & 0.94 & 0.18 \\
\hline Radius & 0.21 & 0.28 & 0.36 & $0.4^{8}$ & 0.37 & 0.39 & 0.09 \\
\hline Uina & 0.28 & 0.29 & 0.50 & 0.86 & 0.46 & 0.81 & $-\ldots$ \\
\hline \multicolumn{8}{|l|}{$\begin{array}{l}\text { Fat-free dry matter } \\
\text { in bone: }\end{array}$} \\
\hline 3 rd metacarpal & $35^{\cdot 2}$ & $36 \cdot 0$ & $35 \cdot 3$ & $37 \cdot 2$ & 393 & $4 x \cdot 2$ & $1 \cdot 02$ \\
\hline $4^{\text {th }}$ metacarpal & $34 \cdot 3$ & 34.9 & $34^{\circ} \circ$ & $37 \cdot 2$ & $39 \cdot 6$ & $41 \cdot 6$ & $1 \cdot 02$ \\
\hline Radius & $39 \cdot 4$ & $39^{\circ} \mathrm{I}$ & $36 \cdot 7$ & 39.5 & $4 I \cdot 5$ & $43 \cdot 3$ & 0.79 \\
\hline Ulna & $37 \cdot 4$ & $39 \cdot 0$ & $37 \cdot 7$ & 39.7 & $43 \cdot 5$ & 447 & - \\
\hline \multicolumn{8}{|l|}{ Ash in fresh bone: } \\
\hline 3rd metacarpal & $16 \cdot 9$ & $16 \cdot 5$ & 15.8 & $17 \cdot 3$ & $19 \cdot 0$ & $20 \cdot 0$ & 0.92 \\
\hline $4^{\text {th }}$ metacarpal & $15 \cdot 7$ & $15 \cdot 5$ & 14.9 & $17 \cdot 5$ & 19.0 & $20 \cdot 6$ & 0.83 \\
\hline Radius & $20 \cdot 2$ & 19.8 & $18 \cdot 0$ & 19.8 & $2 I \cdot 6$ & $22 \cdot 5$ & 0.78 \\
\hline Ulna & $18 \cdot 5$ & $19 \cdot 1$ & 17.9 & $19 \cdot 7$ & $20 \cdot 8$ & $22 \cdot 6$ & 0.82 \\
\hline \multicolumn{8}{|c|}{$\begin{array}{l}\text { Ash in fat-free } \\
\text { dry matter of bone: }\end{array}$} \\
\hline 3rd metacarpal & $48 \cdot 1$ & $45 \cdot 8$ & 447 & $46 \cdot 6$ & $48 \cdot 4$ & $48 \cdot 6$ & $x \cdot 36$ \\
\hline $4^{\text {th }}$ metacarpal & $45 \cdot 8$ & 44.4 & $43 \cdot 8$ & $47 \cdot 1$ & $48 \cdot 0$ & 49.4 & $r \cdot 75$ \\
\hline Radius & $5 I \cdot 4$ & 50.5 & $49 \%$ & $50 \cdot 2$ & $52 \cdot 0$ & $5 I \cdot 9$ & $I \cdot 14$ \\
\hline Ulna & $48 \cdot 9$ & $48 \cdot 9$ & $47 \cdot 8$ & $48 \cdot 3$ & 50.5 & $5 \mathrm{I} \cdot 2$ & -* \\
\hline
\end{tabular}

Table 3. Mean values and standard errors of differences between means for percentage

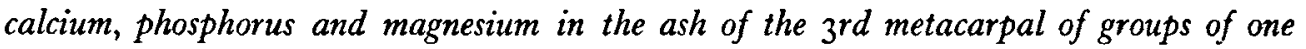
animal from each of four litters of sow-reared piglets slaughtered in turn during the Ist month of life

\begin{tabular}{|c|c|c|c|c|c|c|c|}
\hline $\begin{array}{l}\text { Age at slaughter } \\
\text { (days) } \quad \ldots\end{array}$ & 0 & 2 & 7 & I4 & 21 & 28 & $\begin{array}{l}\text { Standard error } \\
\text { of differences } \\
\text { between means }\end{array}$ \\
\hline $\mathrm{Ca}(\%)$ & $35 \cdot 8$ & $35 \cdot 8$ & $35 \cdot 3$ & $35 \cdot 2$ & $35 \cdot 1$ & $36 \cdot 3$ & 0.45 \\
\hline $\mathrm{P}(\%)$ & $16 \cdot 8$ & 16.9 & 17.5 & $17 \cdot 5$ & 17.5 & $17 \cdot 7$ & 0.16 \\
\hline $\operatorname{Mg}(\%)$ & 0.64 & 0.60 & 0.77 & 0.78 & 0.79 & 0.76 & 0.026 \\
\hline Ratio, Ca:P & $2 \cdot 13$ & $2 \cdot 12$ & $2 \cdot 03$ & 2.02 & 2.00 & $2 \cdot 06$ & 0.03 \\
\hline Ratio, $\mathrm{Ca}: \mathrm{Mg}$ & $56 \cdot 9$ & $59 \cdot 8$ & $46 \cdot 2$ & $45 \cdot I$ & 444 & $47 \cdot 8$ & I.94 \\
\hline
\end{tabular}

Ash content of fat-free dry matter of bones. Analyses of the differences in percentage ash in fat-free dry matter gave variance ratios that were not significant for the 3 rd and

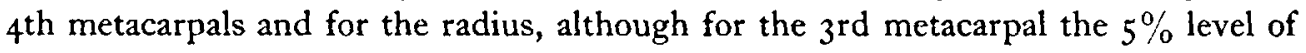


significance was approached. It is therefore unwise to place any reliance on the few instances in which differences between means reached statistical significance.

Mineral composition of the ash. The results for the $3^{\text {rd metacarpal are given in }}$ Table 3. The radius showed the same trends. The percentage of Ca did not vary significantly between ages. The percentages of both $\mathrm{P}$ and $\mathrm{Mg}$ in the ash of the 3 rd metacarpal of newborn and 2-day-old piglets were significantly $(P<0.01)$ lower than those in 7-, 14-, $2 \mathrm{I}$ - and 28-day-old piglets. As a result, the ratios between $\mathrm{Ca}$ and $\mathrm{P}$ and $\mathrm{Ca}$ and $\mathrm{Mg}$ from 7 days onwards were significantly lower than at either 0 or 2 days.

\section{One litter studied over the period from 0 to 140 days of age}

Table 4 summarizes the results for this litter. It can be seen that bones continued to grow rapidly throughout the period. Fat content rose from very low levels before 28 days of age to much higher levels later. Ash content rose considerably after 28 days of age. The chemical composition of the ash varied very little after 28 days of age.

Table 4. Summary of findings about bones of sowv-reared litter-mate piglets slaughtered at intervals from birth to 140 days

\begin{tabular}{|c|c|c|c|c|c|c|c|c|c|c|}
\hline Age at slaughter (days) $\ldots$ & 0 & 2 & 7 & 14 & $2 I$ & 28 & 56 & 84 & 112 & 140 \\
\hline Sex & q & q & む & $\sigma$ & 3 & q & $q$ & $\delta$ & o & $\delta^{8}$ \\
\hline Weight at slaughter (kg) & $1 \cdot 379$ & $x \cdot 878$ & 3.250 & $4 \cdot 656$ & $6 \cdot 520$ & $8 \cdot 44^{8}$ & $22 \cdot 79$ & 43.54 & 63.96 & $81 \cdot 19$ \\
\hline $\begin{array}{l}\text { Fresh weight of bone }(\mathrm{g}) \\
3^{\text {rd metacarpal }} \\
\text { 4th metacarpal }^{\text {Radius }} \\
\text { Ulna }\end{array}$ & $\begin{array}{l}2.450 \\
2.755\end{array}$ & $\begin{array}{l}1 \cdot 193 \\
1 \cdot 055 \\
3 \cdot 361 \\
3 \cdot 570\end{array}$ & $\begin{array}{l}2 \cdot 066 \\
1 \cdot 756 \\
5 \cdot 475 \\
5 \cdot 847\end{array}$ & $\begin{array}{l}2 \cdot 228 \\
6 \cdot 873 \\
7 \cdot 702\end{array}$ & $\begin{array}{r}4.021 \\
3.719 \\
10.912 \\
11.937\end{array}$ & $\begin{array}{r}4.553 \\
4.062 \\
12.799 \\
13.093\end{array}$ & $\begin{array}{r}10 \cdot 35 \\
9 \cdot 07 \\
30 \cdot 92 \\
32 \cdot 27\end{array}$ & $\begin{array}{l}16 \cdot 43 \\
\times 5 \cdot 71 \\
52 \cdot 45 \\
55 \cdot 13\end{array}$ & $\begin{array}{l}22 \cdot 27 \\
20 \cdot 68 \\
76 \cdot 77 \\
82 \cdot 39\end{array}$ & $\begin{array}{l}24 \cdot 34 \\
23 \cdot 97 \\
84 \cdot 68 \\
93 \cdot 29\end{array}$ \\
\hline $\begin{array}{l}\text { Ash in fresh bone }(\%) \\
3^{\text {rd metacarpal }} \\
\text { 4th metacarpal } \\
\text { Radius } \\
\text { Ulna }\end{array}$ & $\begin{array}{l}6 \cdot 7 \\
5 \cdot 9 \\
0 \cdot 7 \\
8 \cdot 3\end{array}$ & $\begin{array}{l}15.4 \\
547 \\
18 \cdot 9 \\
18 \cdot 4\end{array}$ & $\begin{array}{l}14.3 \\
14.4 \\
17 \cdot 9 \\
17 \cdot 5\end{array}$ & $\begin{array}{l}18 \cdot 1 \\
17 \cdot 6 \\
20 \cdot 9 \\
20 \cdot 0\end{array}$ & $\begin{array}{l}17 \cdot 0 \\
16 \cdot 6 \\
20 \cdot 0 \\
18 \cdot 0\end{array}$ & $\begin{array}{l}19 \cdot 1 \\
19.0 \\
21 \cdot 4 \\
21 \cdot 4\end{array}$ & $\begin{array}{l}23 \cdot 7 \\
23 \cdot 1 \\
26 \cdot 1 \\
25 \cdot 3\end{array}$ & $\begin{array}{l}24 \cdot 0 \\
23 \cdot 4 \\
26 \cdot 0 \\
25 \cdot 6\end{array}$ & $\begin{array}{l}26 \cdot 2 \\
26 \cdot 2 \\
28 \cdot 2 \\
27 \cdot 0\end{array}$ & $\begin{array}{l}30 \cdot 1 \\
30 \cdot 1 \\
30 \cdot 9 \\
31 \cdot 0\end{array}$ \\
\hline $\begin{array}{l}\text { bone }(\%) \\
\text { matter }(\%)\end{array}$ & $\begin{array}{c}0.04 \\
35.0\end{array}$ & $\begin{array}{c}0.15 \\
34.8\end{array}$ & $\begin{array}{c}0.20 \\
33.4\end{array}$ & $\begin{array}{c}0.39 \\
37.5\end{array}$ & $\begin{array}{c}0.45 \\
37.1\end{array}$ & $\begin{array}{r}r \cdot 15 \\
40 \cdot 1\end{array}$ & $\begin{array}{l}11.8 \\
43.7\end{array}$ & $\begin{array}{c}? \\
42 \cdot 9\end{array}$ & $\begin{array}{l}19.4 \\
47.4\end{array}$ & $\begin{array}{l}18.6 \\
51.8\end{array}$ \\
\hline $\begin{array}{l}\text { Ash in fat-free dry } \\
\text { matter }(\%) \\
\text { Calcium in ash }(\%) \\
\text { Phosphorus in ash }(\%) \\
\text { Magnesium in ash }(\%)\end{array}$ & $\begin{array}{l}47.7 \\
35.4 \\
16.8 \\
0.61\end{array}$ & $\begin{array}{l}44 \cdot 4 \\
36 \cdot 0 \\
17 \cdot 1 \\
0.62\end{array}$ & $\begin{array}{l}42 \cdot 7 \\
35 \cdot 7 \\
17 \cdot 7 \\
0.78\end{array}$ & $\begin{array}{l}48 \cdot 2 \\
35 \cdot 3 \\
17 \cdot 1 \\
0 \cdot 75\end{array}$ & $\begin{array}{l}46 \cdot 0 \\
34 \cdot 4 \\
17 \cdot 6 \\
0.76\end{array}$ & $\begin{array}{c}47.2 \\
36 \cdot 1 \\
17 \cdot 3 \\
0.70\end{array}$ & $\begin{array}{l}54 \cdot 2 \\
35 \cdot 3 \\
17.5 \\
0.68\end{array}$ & $\begin{array}{c}55.8 \\
36.7 \\
17.5 \\
0.71\end{array}$ & $\begin{array}{c}55 \cdot 2 \\
37 \cdot 3 \\
17 \cdot 3 \\
0.67\end{array}$ & $\begin{array}{c}58 \cdot 1 \\
37.0 \\
17.3 \\
0.68\end{array}$ \\
\hline
\end{tabular}

\section{SCUSSI ON}

Blair, Diack \& MacPherson (1963) reported a radiographic study of the development of certain bones in seven suckled Landrace $\times$ Wessex piglets. At 8 weeks of age these piglets were killed and all the bones in the skeleton were removed for chemical analysis. Milk intake was measured by weighing piglets before and after suckling for $7 \frac{1}{2} \mathrm{~h}$ periods twice weekly. Samples of milk were analysed, and the amounts of Ca and $\mathbf{P}$ found in the skeleton of the piglets at 8 weeks of age, expressed as percentages of ingested $\mathrm{Ca}$ and $\mathrm{P}$, were $67-86$ and $39-47$ respectively. Our investigation does not 
appear to overlap with that of Blair $e$ t al. to any extent. Pullar ( 1960 ) reported a study of bone composition in pigs intended to provide standards for the diagnosis of rickets. However, his material, which included a number of foetuses, was largely of unknown age, and detailed comparison of our results with his would be of little value. Pullar emphasized that it is desirable to use a whole bone for studies of this kind, rather than parts of bones, in order to avoid sampling errors. The other studies that have been made on bone development in pigs (Dickerson, 1962; Kossakowski, 1962a,b) cover a wide range of ages and include the period that we have studied. However, our investigation gives a detailed picture of the changes occurring in bone during the suckling period; the other studies show the trends over a longer period, as does our one litter studied over the period from birth to 140 days of age.

The most noteworthy of our findings is the tendency for the proportion of ash in the bones of the piglet to decrease over the ist week of life. Similar falls in calcium content of bone in suckling animals of other species have been observed and are referred to by Slater \& Widdowson (1962). These authors showed that, in suckling kittens, dosing with $\mathrm{CaHPO}_{4}$ prevented the decrease in degree of calcification that normally occurred. In an experiment in which we have measured the ash content of the whole body of sow-reared piglets (Manners \& McCrea, 1963 ) we found that the proportion of ash in fat-free body tissue falls over the period from birth to 7 days of age, largely owing to a fall in $\mathrm{Ca}$ concentration. It would appear that the sow-reared piglet is short of boneforming minerals during the Ist week of life when both bone weight and body-weight show maximum relative increase. The low $\mathrm{Mg}$ concentration that we observed in bone ash at birth and at 2 days of age compared with that at later ages is in accordance with our finding (Manners \& McCrea, 1963) that $\mathrm{Mg}$ concentration in the whole body of the piglet falls between birth and 2 days of age and rises thereafter.

\section{SUMMARY}

I. Individuals from four litters of sow-reared Large White $\times$ Wessex piglets were slaughtered in turn, a piglet from each litter being killed at $0,2,7,14,21$ and 28 days of age. Additional piglets in one litter were killed at 56, 84, I 12 and 140 days of age.

2. Changes in the chemical composition of the radius, ulna, $3^{\text {rd }}$ and $4^{\text {th }}$ metacarpals were studied. The proportions of fat, fat-free dry matter and ash in the bones were measured and also the calcium, phosphorus and magnesium contents of the ash of the $3^{\text {rd metacarpal. }}$

3. During the Ist week of life, when growth was relatively more rapid than in subsequent periods, the percentage ash in bones fell to a variable extent; thereafter it rose. Fat content of bones was low throughout the ist month of life, in contrast to the high levels in pigs of 56 days of age and older.

4. Both $\mathrm{P}$ and $\mathrm{Mg}$ formed lower proportions of the ash at birth and at 2 days of age than at subsequent ages.

This work was partly financed by a grant from the Agricultural Research Council. Assistance with the chemical analysis of bones was given by Miss P. M. Wakeman. 


\section{REFERENCES}

Blair, R., Diack, J. R. B. \& MacPherson, R. M. (1963). Brit. Y. Nutr. 17, 19.

Bradfield, E. G. (г961). Analyst, 86, 269.

Clark, E. P. \& Collip, J. B. (1925). F. biol. Chem. 63, 461 .

Combs, G. E., Vandepopuliere, J. M., Wallace, H. D. \& Koger, M. (1962). F. Anim. Sci. $21,3$.

Dickerson, J. W. T. (r962). Biochem. $₹ .82,47$.

Hanson, W. C. (1950). F. Sci. Fd Agric. 1, 172.

Kossakowski, J. (1962a). Roczn. Nauk rol. 78B, 627 .

Kossakowski, J. ( ( $962 b$ ). Roczn. Nauk rol. 79 B, 69 .

McCrea, M. R. \& 'Tribe, D. E. (1956). Vet. Rec. 68, 741.

Manners, M. J. \& McCrea, M. R. (1963). Brit. J. Nutr. I7, 495.

Mayo, R. H., Plumlee, M. P. \& Beeson, W. M. (1959). F. Anim. Sci. 18, 264.

Miller, E. R., Ullrey, D. E., Zutaut, C. L., Baltzer, B. V., Schmidt, D. A., Hoefer, J. A. \& Luecke, R. W. (1962). F. Nutr. 77, 7 .

Pullar, E. M. (1960). Aust. vet. F. 36, 31 .

Rutledge, E. A., Hanson, L. E. \& Meade, R. J. (1961). J. Anim. Sci. 20, 243.

Slater, J. E. \& Widdowson, E. M. (I g62). Brit. F. Nutr. 16, 39.

Woodman, H. E. (1957). Bull. Minist. Agric., Lond., no. 48, 14th ed. 